\title{
Impacts of Informal Settlements on Housing Development: The Case of Debre Berhan Town, Amhara Regional State, Ethiopia
}

\author{
Bedasa Asefa \\ Department of Surveying Engineering, Debre Berhan University, Debre Berhan, Ethiopia \\ Email address: \\ badho251@gmail.com \\ To cite this article: \\ Bedasa Asefa, Impacts of Informal Settlements on Housing Development: The Case of Debre Berhan Town, Amhara Regional State, Ethiopia. \\ Landscape Architecture and Regional Planning. Vol. 5, No. 4, 2020, pp. 67-73. doi: 10.11648/j.larp.20200504.12
}

Received: June 10, 2020; Accepted: June 22, 2020; Published: November 23, 2020

\begin{abstract}
The issue of inadequate housing is the difficulty that millions of lower and middle-income groups in urban areas of the developing world face. This study is an assessment of informal settlements and its impacts on housing developments in Debre Berhan town. The core problem identified in this research is the uncontrollable illegal division of lands for substandard housing. The study aimed to examine the characteristics informal settlements focusing on housing standards, causes of Informal settlements including their impacts in the housing developments, the different modes of informal land acquisition mechanisms, evaluating the legal responses for informal settlers to solve these impacts and to propose a possible preventive and curative solution for the informal settlement expansion in the town. The research design employed in the study was a mixed type and the combination of probability and purposive sampling techniques were used. Both quantitative and qualitative data were collected from primary and secondary sources, and the methods of data collection from primary were direct observation, interviews, field questionnaire surveys, and instrumental use. The result of the study of informal settlements in the town was characterized by legal, socioeconomic, and environment due to the inefficiency of the formal land supply process, to deliver adequate land for housing, population growth, urbanization, socio-cultural factors, and others. And the major mechanisms of informal land acquired through purchasing lands from informal land market and inheritance. The physical, social, political, and environmental problems were the impacts that are caused by informal settlements and the local government's response was regulating and demolition. The study recommended the entire land development and management system to address vital areas of strategic physical planning, cadastral surveying, land recording and registration, and wellmanaged land information system to improve the land availability factor in the town and help to control informal settlements. This research will have a positive contribution to promoting the realization of the right to adequate housing with security of tenure for informal settlements in Debre Berhan town.
\end{abstract}

Keywords: Informal Settlements, Squatter Settlements, Impacts, Illegal Sub Division and Slum

\section{Introduction}

Informal Settlements are defined as residential areas of the urban poor more often in the cities of the developing world. They are found on public, private or customary land accessed by invasion or developed against planning, building and ownership regulations [1]. The number of people born in cities and towns increase and as people continues to be displaced from rural areas and this encouraging informal settlement and creates impacts on urban world developments [2]. Most cities/towns in developing countries, expanding horizontally and population are moving to unplanned settlements on the peripheries at the expanse of agricultural lands and areas of natural beauty and they construct substandard house [3].

Informal settlements are a phenomenon that exists in many parts of the world and it involves problems such as substandard living conditions, poor service standards and an absence of secure tenure. It is an accepted fact that rapid population growth hinders development in the third world countries. Because of this fact, around $20 \%$ of the world total populations are thought to be lacking decent housing [4]. 
With regard to the residents of the developing world, it is estimated at least one fifth and perhaps over half of the population, lives in substandard housing. The majority of the population in major cities/towns in the developing world is more than one million people live in illegally or informally developed settlement $[3,4]$. This together with continuing poverty and lack of basic needs like: food, clean water, shelter, basic health care and security of tenures imposing a great challenge for sustainable housing development. Mostly low-quality houses and lack of, inadequate infrastructure and social services characterized informal settlements [5].

The Ministry of Urban Development and Construction of Ethiopia in 2012 also indicated that slum, informal and squatter settlements are steadily growing at alarming rates in major urban centers of Ethiopia rendered the worse for the people already burdened deeply by abject poverty and constrain enormous potential for human development that urban life offer [6].

Since Debre Berhan town is one of a great town in Ethiopia which is found in Amhara National Regional State, the town is on the track of fast redevelopment because it grew as an administrative, industrial zone and commercial center in the country. Due to population growth, expansion of industry and other related factors, Debre Berhan town was unable to satisfy the ever-increasing demands for land and housing in addition to its physical expansion which leads people to informality on the peripheries of the town. Just like any other town of developing countries the town faces many different impacts from informal settlements; the emergence of informal settlements in different sites of the Debre Berhan town affects the harmonious and sustainable development of houses. There are around 3000 informal settlers found in different areas of the town. The informal settlements in this town were becoming great informal issues for town administration and it is necessary investigate or assess informal settlements and its problem in the town is crucial. The main aim of this study is to assess the informal settlements and its impacts on urban housing development in Debre Berhan town. Specifically, the aim of this study; identifying the characteristics of informal settlements focusing on housing standards in the town; identifying causes of informal settlements, including its impacts on housing development in Debre Berhan town; and proposing and recommending the possible preventive for the problem.

\section{Description of the Study Area}

The town of Debre Berhan is located at $130 \mathrm{~km}$ from Addis Ababa on the main road Addis Ababa-Dessie -Mekele road in the Amhara regional state, North Shewa administrative zone, Ethiopia. Taking UTM coordinate system as a reference, the location of the city is nearly between $545000 \mathrm{~m}-570000 \mathrm{~m}$ in the West-East direction and $1060000 \mathrm{~m}-1080000 \mathrm{~m}$ in the South-North direction. The average elevation is approximately $2800 \mathrm{~m}$ above mean sea level. Debre Berhan is one of the oldest and fast-growing towns in Amhara Regional state. The town was established during the conquest of Atse Zara Yaekob towards Northern of the capital, Addis Ababa, Ethiopia. It was since this time that the town has become an important urban center following large scale formal settlement. The town has two main offices, these are the mayor offices led by the mayor and the municipal office which is led by manger that is accountable to the mayor and it is divided in to nine kebeles. Currently the town serves as a capital of North Shewa zone.

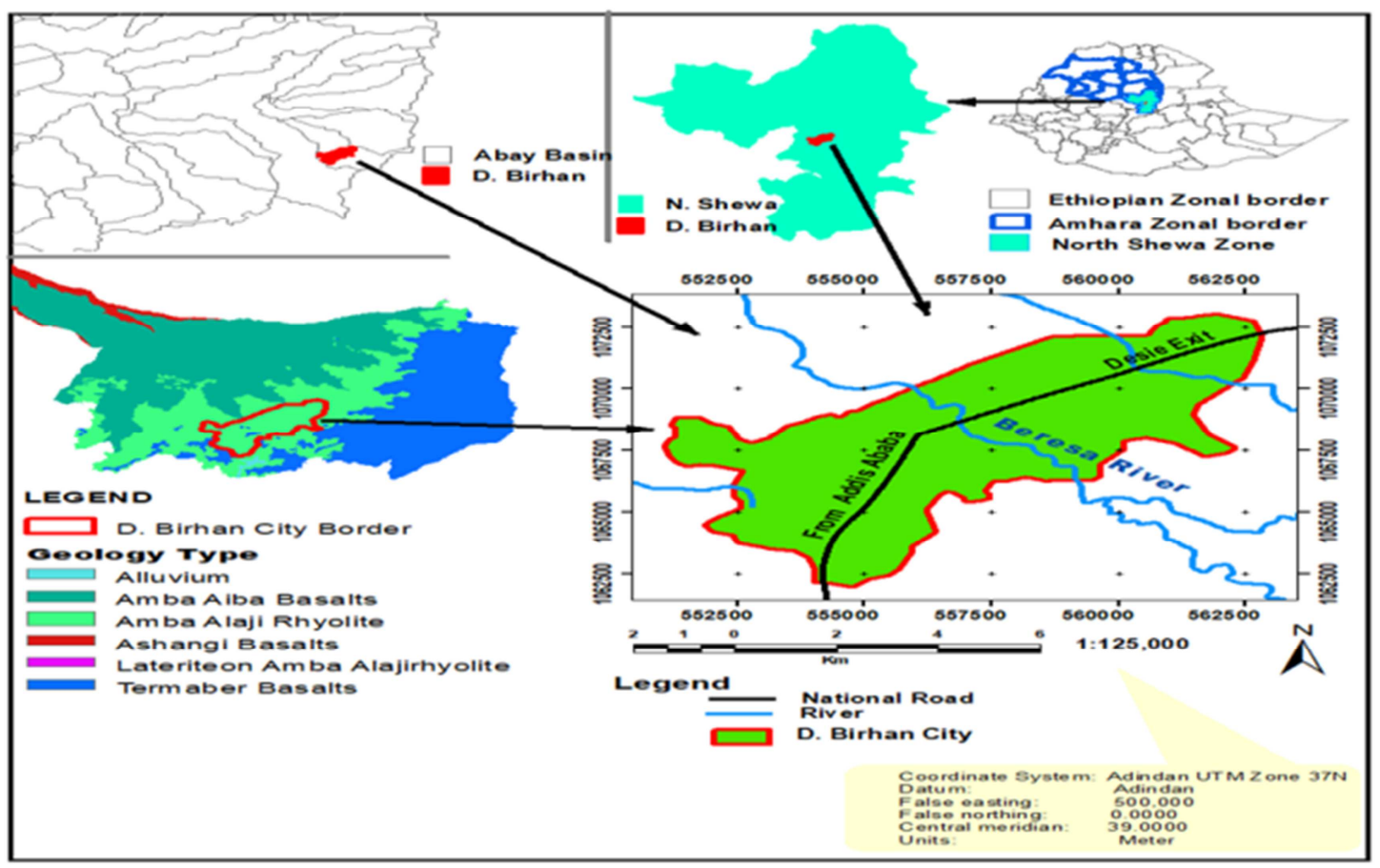

Figure 1. Description of study area. 


\section{Materials and Methods}

To access the informal settlements in Debre Berhan town, the researcher follows descriptive research design methods. And the methods help to describe qualitative and quantitative information obtained from primary and secondary data. But due to the nature of the study, the quantitative approach is more dominantly used and as a supportive to this qualitative method is used so that reliable findings were reached from the analysis of quantitative and qualitative data.

In order to achieve the objective of the study, it is necessary to collect both qualitative and quantitative data. The data for this study was gathered from primary and secondary sources. The primary data sources for this study were both open and close ended questionnaires, interviews, and photographs taken during site observation. The secondary data sources were Central Statistics Agency (CSA), related documents, Books, internet and research papers on related topics, policies and other literatures.

\section{Sample Size}

The populations of the study were the informal settlers who have no legal title deeds in the town. The sampling frame of the study were 3000 (informal settlers who have no title deed) which are registered by the land development and management office of the town. The sampling units for this research were randomly selected households in the study areas of the town. In this study both probability and purposive sampling techniques were used. The probability sampling technique is used to take samples from informal settlers whereas purposive sampling techniques from the land development and management agency and town administration officials. According to the data obtained from the Debre Berhan town Land Development and Management Agency, there are about 3000 informal settlers in the town which are the target population for this study which are recorded by the Land Development and Management Agency of the town. To come up with valid result, the researcher collected primary data from each informal settler of Debre Berhan town. However, due to time and financial constraints, the researcher selects sample representatives of the total households only $50 \%$ and level of confidence is $95 \%$ with $\mathrm{z}$ value of 1.96 and the standard error of $5 \%(0.05)$.

The Kothari formula was applied as [7].

$$
n=\frac{\mathrm{zx}^{2} \cdot \mathrm{P} \cdot \mathrm{qNex}{ }^{2}}{(\mathrm{~N}-1)+\mathrm{zx}^{2} \mathrm{pq}}
$$

Where:

$\mathrm{N}=$ size of population $=3000$

$\mathrm{n}=$ the required sample size

$\mathrm{p}=$ population reliability or frequency estimated for a sample size $\mathrm{n}$, where $=50 \%$ which is taken for all developing countries populations

$\mathrm{q}=1-\mathrm{p}=0.5$

$\mathrm{z}=$ the value of the standard normal variable at $95 \%$ confidence level $=1.96$

$\mathrm{e}=$ margin of error (the precision) considered for this study $=0.08$

Thus, $\mathrm{n}=\frac{z^{2} \cdot P . q N}{e^{2}(N-1)+z^{2} P Q}=\frac{1.96^{2} * 0.5 * 0.5 * 3000}{(0.08)^{2(3000-1)+1.96^{2}+0.5 * 0.5}}=\frac{2881.2}{20.15}=\underline{\underline{142987}} \approx \underline{\underline{143}}$

Therefore, the primary data were collected from 143 households. Since the total populations are 3000 households and the sample households which are selected by using Kothari formula are 143 households, using a systematic sampling method that is the most widely used methods of sampling to select respondent [7].

\section{Data Analysis and Interpretation}

The gathered data were organized, classified, and interpreted by using a combination of qualitative and quantitative analysis in line with the objective of the research Both primary and secondary data were analyzed and interpreted through tactical tools to facilitate the interpretation of the result. Those quantitative data were analyzed using frequency distributions, percentages and charts and interpreted by using tables, maps, and figures. The qualitative data were also analyzed and interpreted in descriptive, explanatory text and narration. Both data were analyzed using GIS, SPSS, and ACCESS Software to make the analysis and interpretation.

\section{Results and Discussion \\ 6.1. Characteristics of Informal Settlements in the Study Area}

Similar to other Informal settlements the dwellers in the Informal settlements are socially integrated or diversified with different parts of the country, different religions, ethnics, family sizes and educational background [8]. Both male and females are educated and middle- and lower-income groups are dwelling in the settlements. About 74.1 percent of the households are married and 50.3 percent of the dweller has three and more than family size. More $44.8 \%$ of the households are migrants from a neighborhood rural area which mean informal settlements are focal points for migrants. The majority of the dwellers are self-employed and they do not have good saving habits in bank, micro finance institute and saving and credit associations. Due to their informality, the settlements are physically deteriorated and having poor infrastructure and social services. 98.6 percent of the houses have no proper foundation; all of the houses are constructed with temporary materials like wood and mud and plastered with cement. Generally, 21 percent of the houses are in fair, 63.6 percent of the houses are in bad and 15.4 percent of the houses are good condition according to the housing standards of the town. Average of family members live in an average land size of 300-500 square meters. $61.5 \%$ were quarter services, $32.2 \%$ were L- shape type of houses, $3.5 \%$ of the sampled households had constructed main 
houses and $2.8 \%$ were the main and service quarter houses. The Informal settlements are located in environmentally sensitive areas and on lands preserved for social service and commerce, according to the structural plan of the town. All of the settlements in the town are formed through illegal subdivision of peasant's land and have no legal documents.

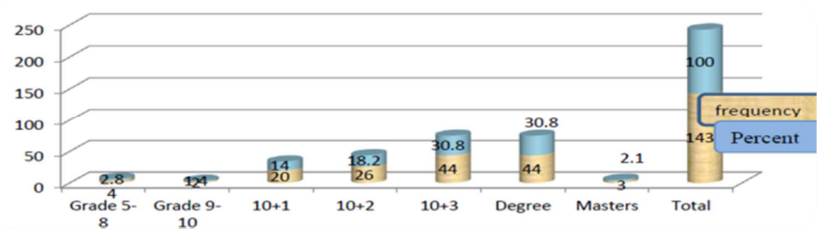

Figure 2. Educational Status of Households.

Table 1. Previous Place of Residence of Respondents.

\begin{tabular}{lll}
\hline Origin of Respondents & Frequency & Percent \\
\hline Debre Berhan Town & 59 & 41.3 \\
Other Neighbourhood Urban Area & 28 & 19.6 \\
Other Urban Center & 30 & 21.0 \\
Neighbourhood, Rural Area & 15 & 10.5 \\
Other & 11 & 7.7 \\
Total & 143 & 100.0 \\
\hline
\end{tabular}

Table 2. Health Status of Respondents.

\begin{tabular}{lll}
\hline Health Status of Respondents & Frequency & Percent \\
\hline Normal & 138 & 96.5 \\
Disable & 5 & 3.5 \\
Total & 143 & 100.0 \\
\hline
\end{tabular}

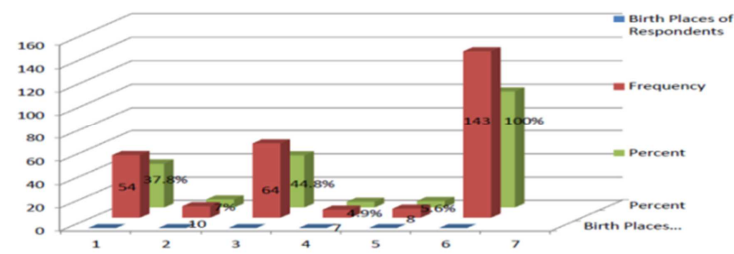

Figure 3. Birth Places of Respondents.

Table 3. Employment of Respondent.

\begin{tabular}{lll}
\hline Employment of Respondents & Frequency & Percent \\
\hline Farmer & 13 & 9.1 \\
Employed by the NGO & 8 & 5.6 \\
Government employed & 77 & 53.8 \\
Private or self employed & 45 & 31.5 \\
Total & 143 & 100.0 \\
\hline
\end{tabular}

Table 4. Source of fund for Construction

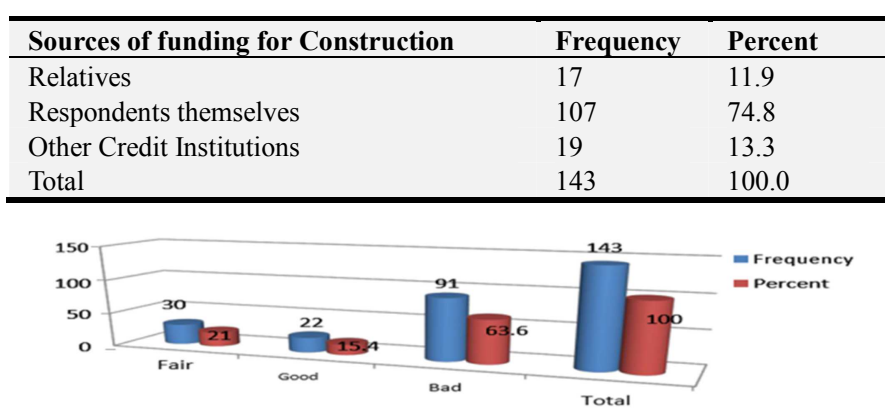

Figure 4. Housing Condition of Respondents.

Table 5. Housing amenities.

\begin{tabular}{lllllll}
\hline \multirow{2}{*}{ Response } & Kitchen availability & \multicolumn{2}{c}{ Shower Availability } & \multicolumn{2}{c}{ Toilet availability } \\
\cline { 2 - 7 } & Frequency & \% & Frequency & \% & Frequency & \% \\
\hline Yes & & & - & - & & \\
No & & 59 & 41.3 & 7 & 4.9 \\
Modern & 143 & 100.0 & 31 & 37.1 & & \\
Substandard & 143 & 100.0 & 143 & 21.7 & 136 & 95.1 \\
Total & & & 100.0 & 143 & 100.0 \\
\hline
\end{tabular}

Table 6. Access Circulation of houses.

\begin{tabular}{lll}
\hline Access, Circulation of Houses & Frequency & Percent \\
\hline Pedestrian & 102 & 64 \\
Asphalt road & 10 & 14.3 \\
Vehicle Access & 31 & 21.7 \\
Total & 143 & 100.0 \\
\hline
\end{tabular}

Table 7. Infrastructure of Houses of Respondents.

\begin{tabular}{|c|c|c|c|c|c|c|}
\hline \multirow{2}{*}{ Responses } & \multicolumn{2}{|l|}{ Water supply } & \multicolumn{2}{|c|}{ Electric Supply } & \multirow{2}{*}{$\begin{array}{l}\text { Telephone } \\
\text { Frequency }\end{array}$} & \multirow{2}{*}{ Percent } \\
\hline & Frequency & Percent & Frequency & Percent & & \\
\hline Yes & - & - & - & - & 13 & 9.1 \\
\hline No & 48 & 33.6 & 47 & 32.9 & 130 & 90.9 \\
\hline Mater shared & 39 & 27.3 & 52 & 36.4 & - & - \\
\hline Mater Private & 56 & 39.2 & 44 & 30.8 & - & - \\
\hline Total & 143 & 100.0 & 143 & 100.0 & 143 & 100.0 \\
\hline
\end{tabular}

Table 8. Energy Use for Cooking in Houses.

\begin{tabular}{lll}
\hline Type of Energy Use for Cooking & Frequency & Percent \\
\hline Wood and Charcoal & 87 & 60.8 \\
Electric Power & 56 & 39.2 \\
Total & 143 & 100.0 \\
\hline
\end{tabular}


Table 9. Legal Ownership of Houses of Respondents.

\begin{tabular}{lllll}
\hline \multirow{2}{*}{ Response Rate } & \multicolumn{3}{l}{ Ownership Type of Houses } & \multirow{2}{*}{ Percent } \\
\cline { 2 - 4 } & Frequency & Percent & Frequency & \\
\hline Yes & 4 & 2.8 & - & - \\
No & 139 & 97.2 & - & - \\
Their Own & - & - & 143 & 100.0 \\
Total & 143 & 100.0 & 143 & 100.0 \\
\hline
\end{tabular}

\subsection{Major Causes of Informal Settlements in the Study Area}

Population growth: population size of the town has increased rapidly in the past two decades due to its urban function like center of administration of the zone, recreational, educational, commercial, cultural, tourism and other different services and activities.
Urbanization: when the built-up area of the town expanding and close to farm land of the peasants, they sell their farm land informally and by other agricultural land far away from the town. This is a massive urbanization in the town due to population growth.

Poverty (unaffordable formal land market for low- and middle-income groups): The cost of land formally of the lease, auction and in informal land market are quite different regardless of plot size and other bureaucratic procedures for residential houses in the town. Insufficient planning, unrealistic zoning, inconsistent and complex regulation and financial constraint of the land development and management to pay appropriate compensation for farmers is the other factor that pushes people to informality due to fear of expropriation.

Table 10. Population Growth Rate.

\begin{tabular}{lll}
\hline Years & Total population & Population Growth Rate \\
\hline $1984-1994$ & 25,491 & $4.11 \%$ \\
$1994-2008$ & 60,729 & $6.2 \%$ \\
$2008-2018$ & 112,899 & $6.2 \%$ \\
\hline
\end{tabular}

Table 11. Reason for Preference of Informal Option.

\begin{tabular}{lll}
\hline Major causes of informality & Frequency & $\mathbf{\%}$ \\
\hline Cumbersome procedures of Land Development and Management & 41 & 28.7 \\
Location preference & 15 & 10.5 \\
Inability to afford the building Standards of the town & 17 & 11.9 \\
Inability to afford the price of land in the formal land market & 41 & 28.7 \\
Need to have large plot size & 25 & 17.5 \\
Other & 4 & 2.8 \\
Total & 143 & 100.0 \\
\hline
\end{tabular}

\subsection{Impacts of Informal Settlements in Housing Developments in Debre Berhan Town}

Despite the above-mentioned positive facts Informal settlements are the center of social evils and below standard life for most people residing in this town. Some of the impacts of the presence of Informal settlements are social, economic, political, physical and environmental problems are Lack of basic infrastructure and services, that creates burdens on the inner town; Lack of legal ownership prevents them from using their house as collateral with a financial institution; Poor living standard housing condition, exposure to the flooding problem, unplanned expansions of the town or deformed parceling and blocks and urban sprawl and excessive encroachment of fertile agricultural land; Environmental pollution, disposing waste on the open space field and on the roads and pedestrian walkways and Land disputes, Political instability, and Social disparity.

\subsection{Modes Informal Land Acquisition Mechanisms}

The main mechanisms of informal land acquisition modes in the town are inheriting and purchasing from informal land market. People who acquire land market gather information about the informal land market and suitability of the sites from brokers, relatives, friends and corrupt local government employees. The actors in the informal market of the town are peasants, land speculators, prior squatter, native farmers, brokers and some corrupt administrative and security workers.

\subsection{Local Government Responses Towards Informal Settlements}

The town administration of the study area has taken positive and negative responses towards the informal settlements. Demolition is the negative measure taken by the town and the positive responses undertaken is regularization according to the land use of the structural plan of the town. Consequently, this regularization of informal settlement has encouraged the formation of new squatter settlements around the peripheries of the town.

\section{Recommendations}

\subsection{Administration and Land Development Management Agency}

Debre Berhan town administration should pop up preparation of plots and continues provision of land for housing through check and balance approach among different section of the Land Development and Management Agency of the town in activities like surveying, planning, 
socioeconomic assessing, land delivery and allocation, legal activities and others. Debre Berhan town administration should give attention to provide house affordable to lower and medium income groups by subsidizing the development and land alternative for social housing programs and attract and encourage community-based organization by initial cost of the lease system of the town to prevent newly formed informal settlements. The government should also revise Regulation for payment of Compensation for lands property and increase the rate of compensation to be paid for expropriate which currently very low when compared to the current market and lease prices and considering the location of the site.

\subsection{Planning Implementation Department}

The study also recommended the planning implementation department creating strategies like physical planning with well managed by land information system, cadastral surveying, land recording and registration to improve the land availability for housing and help to control Informal settlements. Efficient planning and development controlling mechanisms; by preparing proper land use plan, efficient land management and servicing the town can control the encroachment of informal settlements on to good agricultural land and growth of settlement without guiding plan.

\subsection{Land Development and Management Agency}

Legalizing and regularizing in the informal dwellers should be done based on the urban land lease of the country and supported by regulation by making the area economically active by creating opportunities for informal settlers and informal market actors to enhance their skills by creating different mechanisms such as giving training, organizing access to credit by establishing a different association through micro and small enterprises sectors.

\subsection{Recommendation for Further Study}

Since long ago, access to land for housing, especially in urban centers around Addis Ababa and even in other urban centers in Ethiopian continues to challenging and how to improve supply of land especially for lower- and middleincome groups needs more attention and further study. Secondly, the demand of land for housing in bigger urban centers is rapidly increase than the capacity of the urban center to supply lands to provide other urban services. This is because of high migration from rural areas and other smaller urban centers by weak pull and strong push factors. So further study is recommended on how to reduce these push factors from rural and other smaller urban centers so that urbanization of rural and urban centers be accelerated and people could get every service and facilities by being they are.

\section{Conclusion}

Although there are no written documents which describes the exact time when the informal settlements were started in Debre Berhan town, some information from the town administration in the town show that the informal settlements might started before 20 years according to interview of land administration officials and secondary data. The common characteristics of informal settlements such as illegal and informally, inappropriate location, restricted public and private sector investment, poverty and vulnerability and social stress are also the social, economic, physical, environmental and legal characteristics of informal settlements in Debre Berhan town. For instance, poor or inadequate infrastructure provision, lack of saving potable water, poor construction materials of houses or substandard construction materials, lack of the inner house infrastructures like toilet, shower service, vulnerability to hazards such as flooding are prevalent in the informal settlements are the common characteristics in the town. Moreover, insecurity of tenure, lack of standard planning and land use planning, lack of infrastructure, poor environment condition, lack of public facilities, unemployment and poverty are the other characteristics that affect the housing development of the study area of the town.

The settlement accommodates not only low-income groups, but also there are middle income group societies. These settlements are well educated, migrants, natives, civil servants, private employees, farmers, married, unmarried and owner of the houses among the dwellers of informal settlements.

These informal settlements acquire local land from illegally subdivided through inheritance and selling by the major actors of informal land market such as farmers, peasants, land speculators, brokers, prior squatters and corrupt persons. Although there had been some demolishing measures carried out by the town administration and regularization of some neighborhoods and inner informal settlements due to political influence in the town and there have not been efficient and sound measures taken by the town administration of the town because of the overthrow expansion of the different parts of the town. As a result, the rate of informal settlements expansion has been increased from time to time and the administration office are missing large amounts of revenue. Those issues discussed above lead us to conclude that informal settlements having impacts of the current and future development of houses of the town.

\section{References}

[1] Abbott J. and Douglas D (1999) trends in informal settlements, in the Cape of Metropolitan Areas, report Prepared by urban GIS group.

[2] HN-Habitat. (2003). the Impacts of Slum. Nirobi, Kenya.

[3] Minwuyelet. M. (2005). City Expansion, Squatter Settlements and Policy Implication. Addis Ababa, Ethiopia.

[4] Brown, E. G. (2012). Division of Housing Policy Development. Department of Housing and Community Development California. 
[5] Azeb, K. (n.d.). Housing for the Poor in Addis Ababa. Addis Ababa, Ethiopia.

[6] Gossaye, B. (2007). Learning from Informal Settlements, the Case of Adama City, master's Thesis. ECSU, Addis Ababa.

[7] Kothari, CR; 2004, "Research methodology"; New age publication, 2nd edition, pp84-86.

[8] Bunn. S and Williams. J. (1983). Cities of the World, World Regional Urban Development. New York: New Yor Chapman Published Ltd.
[9] Gebeyehu Abelti, Marco Brazzoduro, Behailu Gebremedhin. (2001, October). Housing Conditions and Demand for Housing in Urban Ethiopia. National Research Council (IrpCnr). Addis Ababa, Roma, Italy: CSA - Central Statistical Authority, University of Roma.

[10] Kebena Diriba1 and T. V. Krishna2. (n.d.). Housing Conditions of Public and Private Sector Workers in Gimbi Town, Ethiopia Volume no. 2, informal settlementsue no. 5. National Monthly Refered Journal of Research in Science \& Technology, 24. 